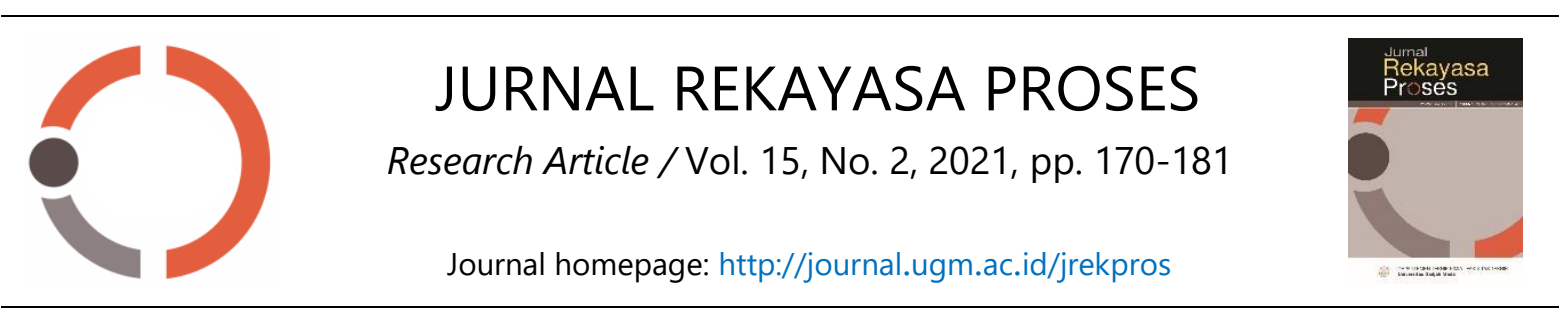

\title{
Characteristics and Kinetics Study of Glycerolabietate from Glycerol and Abietic Acid from Rosin
}

\author{
Danang Tri Hartanto ${ }^{1 *}$, Rochmadi ${ }^{1}$, Meiga Putri Wahyu ${ }^{1}$, and Diastari Kusumawati ${ }^{1}$ \\ ${ }^{1}$ Department of Chemical Engineering, Faculty of Engineering, Universitas Gadjah Mada \\ JI Grafika No. 2 Kampus UGM, 55281 Yogyakarta \\ *Corresponding author: danang.tri.h@ugm.ac.id
}

(Submission: 17-09-2021; Revision: 04-11-2021; Acceptance: 16-11-2021)

\section{A B S T R A C T}

Rosin is a natural resin from the coniferous tree sap, which separated from its oil content (terpenes). Rosin is brittle. Therefore modifications are needed to improve its mechanical properties. The main content of rosin is abietic acid which has a carboxylic group, so it can form an ester group when reacted with polyhydric alcohol (polyalcohol) such as glycerol. The research aimed to study the kinetics of the esterification reaction between the hydroxyl group in glycerol and the carboxylic group in abietic acid from rosin at various reaction temperatures and reactant compositions. This reaction is carried out in a three-neck flask at atmospheric pressure without a catalyst. The reaction temperatures used were $180^{\circ} \mathrm{C}, 200^{\circ} \mathrm{C}$, and $220^{\circ} \mathrm{C}$, and the ratio of rosin and glycerol was 1:1, 1:3, and 1:5. The reaction kinetics calculations were analyzed with acid number data over the reaction time using three different models. The calculations showed that this reaction involves positioning a hydroxyl group on glycerol, which the primary and secondary hydroxyl groups contribute to forming a rosin ester (glycerolabietate). The rate of reaction constants of primary hydroxyl of glycerol and abietic acid were in the range $6.25 \times 10^{-4}-3.90 \times 10^{-3} \mathrm{~g} /\left(\mathrm{mg}_{\text {eq }}\right.$. $\left.\mathrm{min}\right)$, while reaction rate constants of secondary hydroxyl and abietic acid were in the range $1.06 \times 10^{-5}-1.15 \times 10^{-4} \mathrm{~g} /(\mathrm{mg}$ eq. $\mathrm{min})$. FTIR analysis showed a change in the hydroxyl, carboxylate, and ester groups which were assigned by a shift of wavenumber and a difference of intensity at $3200-3570 \mathrm{~cm}^{-1}, 1697.36 \mathrm{~cm}^{-1}$, and $1273.02 \mathrm{~cm}^{-1}$.

Keywords: acid number; glycerol; glycerolabietate; hydroxyl group; rosin-ester

\section{ABSTRAK}

Gondorukem merupakan produk yag berasal dari getah batang tanaman pinus yang sudah dipisahkan kandungan minyaknya (terpena). Gondorukem memiliki sifat yang getas, oleh karena itu diperlukan modifikasi untuk meningkatkan sifat mekaniknya. Dengan kandungan utamanya asam abietat yang memiliki gugus karboksilat, gondorukem berpotensi membentuk gugus ester apabila direaksikan dengan senyawa alkohol polihidrik (polialkohol) seperti gliserol. Penelitian 
bertujuan untuk mempelajari kinetika reaksi esterifikasi antara gugus hidroksil pada gliserol dan gugus karboksilat pada asam abietat dari gondorukem pada variasi suhu reaksi dan komposisi reaktan. Reaksi ini dilakukan dalam labu leher tiga tanpa katalis pada tekanan atmosferis. Suhu reaksi yang digunakan ialah $180^{\circ} \mathrm{C}, 200^{\circ} \mathrm{C}$, dan $220^{\circ} \mathrm{C}$ dan perbandingan gondorukem dan gliserol 1:1, 1:3, dan 1:5. Analisis perhitungan kinetika reaksi didekati dengan data bilangan asam tiap waktu menggunakan tiga model berbeda. Hasil dari simulasi perhitungan menunjukkan bahwa reaksi ini melibatkan posisi gugus hidroksil pada gliserol, yang mana gugus hidroksil primer dan sekunder memiliki kontribusi untuk mem-bentuk rosin ester (glycerolabietate). Konstanta laju reaksi antara hidroksil primer pada gliserol dengan asam abietat dalam rentang $6.25 \times 10^{-4}-3.90 \times 10^{-3} \mathrm{~g} /\left(\mathrm{mg}_{\text {eq. }} \mathrm{min}\right)$, sedangkan konstanta laju reaksi antara hidroksil sekunder pada gliserol dengan asam abietat dalam rentang $1.06 \times 10^{-5}-1.15 x$ $10^{-4} \mathrm{~g} /\left(\mathrm{mg}_{\text {eq. }} \mathrm{min}\right)$. Analisis FTIR menunjukkan bahwa adanya perubahan gugus hidroksil, karboksilat, dan ester yang ditandai terjadinya pergeseran dan perbedaan intensitas pada angka gelombang $3200-3570 \mathrm{~cm}^{-1}, 1697,36 \mathrm{~cm}^{-1}$, dan $1273,02 \mathrm{~cm}^{-1}$.

Kata kunci: bilangan asam; gliserol; gondorukem; gugus hidroksil; rosin-ester

\section{Introduction}

The environmentally friendly products are attractive for the world market. In addition to providing convenience to consumers, the export costs charged for products labelled as environmentally friendly are lower. One of the natural ingredients that can be used as a polymer for coating material applications is rosin (Xu et al., 2019; Domene-López et al., 2018; Kumooka, 2008). Rosin (resina colophonium) is a resin produced from the sap of coniferous plants such as pine (Kugler et al., 2019). Rosin is a non-volatile resin with an abietic acid content of $70 \%$, and the rest is pimaric acid and its isomers (Ladero et al., 2011; Gandini and Lacerda, 2015). Rosin has several weaknesses, which is brittle (Kugler et al., 2019). Therefore, modification of rosin is needed. In order to improve the mechanical properties of rosin, modifications are required with various substances. Most coatings are commercially produced from petroleumbased, so the sources were scarce. Abietic acid has a carboxylic group that has the potential to form ester substances that enable polymerization, cross-linking, and polymer matrix (Kugler et al., 2019). Some of the applications of rosin as coatings (Su et al., 2021), adhesives (Kumooka, 2008), and packagings (Hsieh and Chen, 2020).

Characterization of rosin before and after synthesis became essential. One way was to observe the functional groups of untreated and treated rosin. The presence of an ester group in the product will produce a coating that has better mechanical properties. In addition, a kinetic study was carried out because the mathematical modelling related to the rate of reaction modification of rosin was still limited. At the same time, rosin-based synthesis continues to be developed to reach an industrial scale (Ladero et al., 2011).

Research (Ladero et al., 2012) conducted a study on the reaction rate between abietic acid, glycerol, and pentaerythritol. The reaction rate model produced from this process is a first-order reaction model with excess rosin reactants. The reaction of rosin and glycerol can be improved by adding 
catalysts such as rare earth Lewis acidic ionic liquid (Sun et al., 2021) and enzymes such as lipase (Lin et al., 2014). Rosin can also be modified with maleic anhydride to produce a coating material on urea fertilizer to control the release of the soil (Mumtaz et al., 2019).

The reaction of this is research was the esterification of abietic acid and glycerol. Pure rosin is brittle because its structure consists of a cyclic ring. Therefore, an improvement is needed. One modification is to react the carboxylic group on abietic acid and the hydroxyl group on glycerol to become an ester compound.

The study aimed to study the kinetics of the esterification reaction between the hydroxyl group in glycerol and the carboxylic group in abietic acid from rosin at various reaction temperatures and reactant compositions. Products with various characters are obtained from these variations and then analyzed which to meet the coating criteria according to the standard. Application rosin-ester of this research was addressed as the organic coating material. Criteria and standard material properties such as tensile strength and elongation of the organic coating were followed on the ASTM D2370 98 and ASTM D-638. By applying some knowledge, it is expected that this research will produce coatings from rosin that are environmentally friendly and have excellent properties that can compete in the international market.

\section{Research Methodology}

\subsection{Materials}

Materials used in this research are rosin (PT. Perhutani Anugerah Kimia, Trenggalek, Indonesia) and glycerol (85\% purity Merck, Germany) was employed as a reactant, sodium hydroxide $(99 \%$ purity Merck, Germany), and ethanol absolute (99\% purity Merck, Germany) was employed as titrant for acid-base titration, and methanol was employed as rosin and glycerolabietate solvent.

\subsection{Procedures}

Rosin was messed, then put in a three-neck flask together with glycerol with a specific ratio. The reaction was conducted at $180^{\circ} \mathrm{C}$ for 3 hours assembled with a $200 \mathrm{rpm}$ mechanical stirrer. At a certain time, samples were taken to be analyzed for $\mathrm{COOH}$ concentration (acid number). After the reaction time was achieved, the reaction product was washed using distilled water to remove the remaining polyol. Next, the product was put in an oven at $60^{\circ} \mathrm{C}$ to remove water content. The experiment was repeated at various reaction temperatures, $180^{\circ} \mathrm{C}, 200^{\circ} \mathrm{C}$, and $220^{\circ} \mathrm{C}$, and various rosin:glycerol ratios at 1:1; 1:3; and 1:5.

The procedure and calculation of determining the acid number of rosin followed the research of Bult et al., 2008. Acid number analysis is carried out by dissolving $0.5 \mathrm{~g}$ of sample in $20 \mathrm{~mL}$ methanol. These samples were titrated with alcoholic- $\mathrm{NaOH}$ $0.1 \mathrm{~N}$. The alcoholic- $\mathrm{NaOH}$ titration volume was obtained and analyzed by Equation (1) as an acid number.

$$
\text { Acid number }=\frac{V_{\mathrm{NaOH}}}{m_{\text {sample }}} x N_{\mathrm{NaOH}}
$$

The functional group of rosin and glycerolabietate was analyzed by Shimadzu IR Prestige-21 FTIR (Fourier Transform Infrared) Spectrophotometer. Samples and $\mathrm{KBr}$ were prepared in a ratio of 1:200 and homogenized with a vibrating mill. The mixture was formed in pellets by pressing and vacuuming. The pellets were scanned with an FTIR 
spectrophotometer, which obtained \%T (percent transmittance) data at a resolution of 16 in ten scans. The \%T obtained was the average data of ten scans. The analysis provided \%T and wavenumber $\left(\mathrm{cm}^{-1}\right)$ data. These data were interpreted by following the wavenumber to address the functional group listed in Coates, 2000.

\subsection{Modelling}

The reaction between abietic acid (rosin) and glycerol was esterification because this reaction involved the carboxylic group ($\mathrm{COOH})$ of abietic acid and hydroxyl group ($\mathrm{OH})$ glycerol. This reaction can be classified as a condensation polymerization reaction because both groups are reacted to form an ester group (glycerolabietate). The proposed reaction models observed the effect of the hydroxyl position on glycerol, which were primary hydroxyl and secondary hydroxyl. These models were distinguished into three models. The schematic reaction was approached by the research of Sun et al., 2021 and Ladero et al., 2012. Esterification reaction abietic acid and each hydroxyl group on glycerol were depicted in Figure 1.

\section{Model I}

This model assumes that the reaction esterification between the carboxylic and hydroxyl groups was reversible (Hartanto et al., 2020; Caballero et al., 2019). Each hydroxyl group position has the opportunity to react with the carboxylic group on abietic acid. The reaction equation can be expressed in Equations (2) and (3).

$$
\begin{aligned}
& R+G_{p} k_{1} \rightleftarrows k_{-1} C \\
& R+G_{s} k_{2} \rightleftarrows k_{-2} D
\end{aligned}
$$

Based on Model I, the concentration of each species depends on time, which can be followed by Equation (4) to (8).

$$
\begin{aligned}
& \frac{d C_{G_{p}}}{d t}=-k_{1} C_{R} C_{G_{p}}+k_{-1} C_{C} \\
& \frac{d C_{G_{S}}}{d t}=-k_{2} C_{R} C_{G_{s}}+k_{-2} C_{D}
\end{aligned}
$$<smiles>CC(C)C1=CC2=CCC3[C@](C)(C(=O)O)CCC[C@]3(C)[C@@H]2CC1</smiles>

Abietic acid<smiles>CC(C)C1=CC2=CCC3[C@@](C)(C(=O)O)CCC[C@]3(C)C2CC1</smiles>
Abietic acid<smiles>OCC(O)CO</smiles>

Glycerol

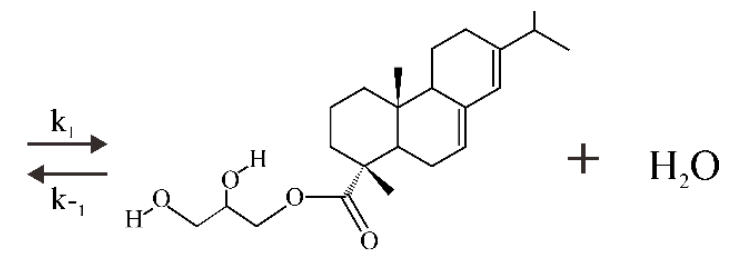

Glycerolabietat (primary)

Water

(a)

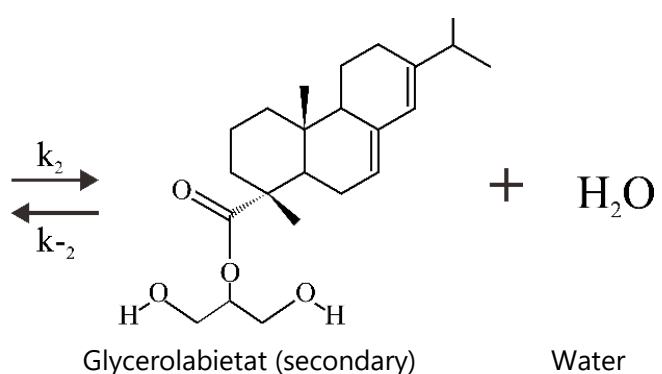

(b)

Figure 1. Schematic of the chemical reaction abietic acid with primary hydroxyl (a) and secondary hydroxyl (b) on glycerol. 


$$
\begin{gathered}
\frac{d C_{C}}{d t}=k_{1} C_{R} C_{G_{p}}-k_{-1} C_{C} \\
\frac{d C_{D}}{d t}=k_{2} C_{R} C_{G_{s}}-k_{-2} C_{D} \\
\frac{d C_{R}}{d t}=-k_{1} C_{R} C_{G_{p}}+k_{-1} C_{c}-k_{2} C_{R} C_{G_{s}}+k_{-2} C_{D}
\end{gathered}
$$

\section{Model II}

Model II was a simplification of Model I, in which there was a reduction in the parameters of the rate reaction. This model was described that the reaction of abietic acid and each hydroxyl group on glycerol was irreversible. It assumed that the water as a byproduct of the reaction was quickly eliminated because the reaction temperature was far above its boiling temperature, then condensed water was immediately collected (Hartanto et al., 2020; Heriyanto et al., 2013). This model can be written on Equations (9) and (10).

$$
\begin{aligned}
& R+G_{p} k_{1} \rightarrow C \\
& R+G_{S} k_{2} \rightarrow D
\end{aligned}
$$

Based on Equations (9) and (10), the concentration of each species of reaction can be expressed following Equations (11) to (15).

$$
\begin{aligned}
& \frac{d C_{G p}}{d t}=-k_{1} C_{R} C_{G_{p}} \\
& \frac{d C_{G_{S}}}{d t}=-k_{2} C_{R} C_{G_{S}} \\
& \frac{d C_{C}}{d t}=k_{1} C_{R} C_{G_{p}} \\
& \frac{d C_{D}}{d t}=k_{2} C_{R} C_{G_{S}} \\
& \frac{d C_{R}}{d t}=-k_{1} C_{R} C_{G_{p}}-k_{2} C_{R} C_{G_{S}}
\end{aligned}
$$

\section{Model III}

Model III Model III neglected the position hydroxyl group on glycerol, and the reaction was irreversible based on a previous study (Ladero et al., 2012). The reaction equation can be declared on Equation (16).

$$
R+G k_{1} \rightarrow C
$$

The concentration of each species depends on time, can be formulated, which was expressed in Equation (17) to (19).

$$
\begin{aligned}
& \frac{d C_{G}}{d t}=-k_{1} C_{R} C_{G} \\
& \frac{d C_{C}}{d t}=k_{1} C_{R} C_{G} \\
& \frac{d C_{R}}{d t}=-k_{1} C_{R} C_{G}
\end{aligned}
$$

\section{Calculation of reaction rate constants}

Reaction rate constants in the three models were analyzed by Matlab 2016b using the average relative error method by calculating the percentage of differences of observed acid number of data and the calculated acid number of each model against the calculated acid number of each model. In prior, the reaction rate constants were guessed, then the differential equations of each model were integrated using the ODE function. If the average relative error didn't give a minimum value, the guessed reaction rate constants would be changed to provide the lowest average relative error value until the calculation stops. The reaction rate constants were obtained if the lowest value of average relative error was attained.

Furthermore, the most suitable model was selected by the lowest average relative error. Every reaction rate constant will be investigated using the Arrhenius equation (Equation (20), and the value of A (preexponential factor) and Ea (activation energy) were analyzed by Equation (21).

$$
\begin{aligned}
& k=A e^{-\frac{E_{a}}{R \cdot T}} \\
& \ln \ln k=\ln \ln A-\frac{E_{a}}{R \cdot T}
\end{aligned}
$$




\section{Results and Discussion}

This esterification reaction was used to make the chain of abietic acid longer, then expected that it was more flexible. Glycerol was one substance that could react with the carboxylic group of rosin. The reaction in this study was esterification, in which there was an interaction between the hydroxyl group of glycerol and carboxylic acid of abietic acid. The product of this reaction was glycerolabietat. Based on the hydroxyl position of glycerol, the reaction's product consists of primary glycerolabietate and secondary glycerolabietate. The acid numbers original rosin was $3.2350 \mathrm{mg} / \mathrm{eq}$. The ratio between the number of primary and secondary hydroxyl groups in glycerol was based on the theoretical number of $-\mathrm{OH}$ groups in glycerol, which is 2:1. The results of the esterification were analyzed for acid numbers by being dissolved in methanol and titrated using $\mathrm{NaOH}$-alcoholic. The acid number was plotted at a certain time and then observed by some proposed models. The product characterization was carried out by analyzing its functional groups to identify the hydroxyl group on glycerol and the carboxylate group on the rosin that was consumed to form an ester group.

This study used a ratio of rosin: glycerol (R:G) of $1: 1 ; 1: 3$; and $1: 5(\mathrm{w} / \mathrm{w})$ at a constant temperature of $180^{\circ} \mathrm{C}$. Figure 2 showed that the longer the reaction time, the acid number was lower. It indicated that the carboxylate group on the rosin would be consumed because it reacted with the hydroxyl group on the glycerol. The three proposed models had a similar graph trend but had a different gradient. $R: G=1: 1$ had the lowest gradient compared to $R: G=1: 3$ and 1:5. The amount of glycerol (hydroxyl group) that was more caused the number of carboxylic groups to be consumed more so that the decrease in the acid number was sharper.

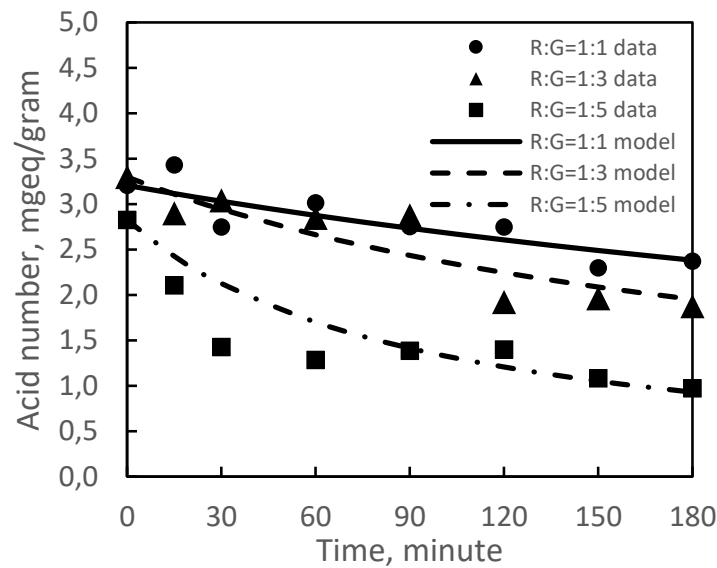

(a)

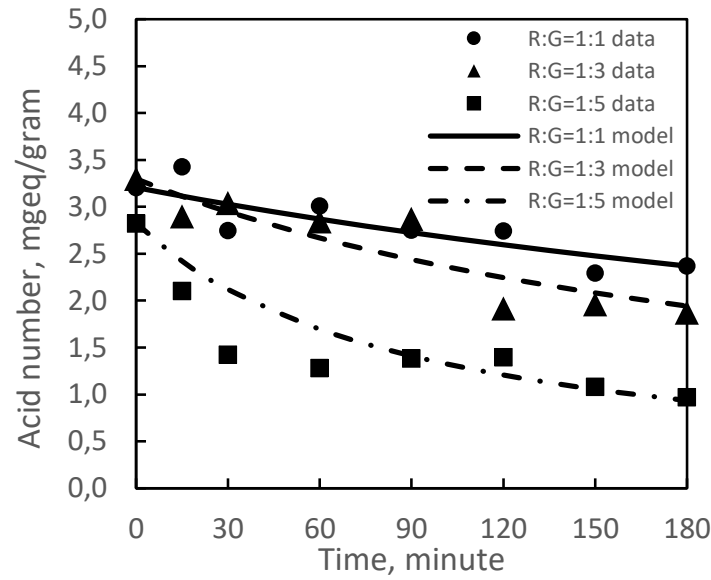

(b)

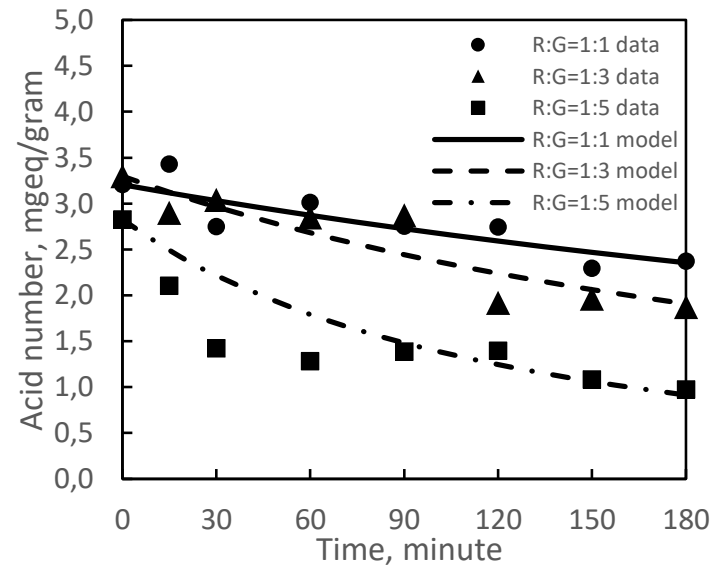

(c)

Figure 2. Data fitting of the acid number on the varying ratio of rosin:glycerol ( $R: G)$ using Model I (a), Model II (b), and Model III (c). 
The study used three approached model to investigate the reaction kinetics between glycerol and abietic acid. The Model I assumes that the reaction was elementary, in which one molecule of abietic acid reacts with one molecule of glycerol. This reaction was a polycondensation reaction because the interaction of the hydroxyl group and the carboxylic group (esterification) produces a byproduct in the form of water which causes a reversible reaction (Satriana and Supardan, 2008). Model II assumed that the reaction was elementary and irreversible. This reaction was assumed to be irreversible because the water formed in small numbers, immediately evaporated, and collected in a container assembled with a three-neck flask condenser (Hartanto et al., 2020). Model III assumed that the reaction between the carboxylate did not consider the position of the hydroxyl group.

Model I had a relative error of $\mathrm{R}: \mathrm{G}=1: 1$; $1: 3$; and $1: 5$ are $4.79 \%$, respectively; $7.42 \%$; $12.02 \%$, model II had a relative error at R:G = $1: 1 ; 1: 3$; and $1: 5$ at $4.81 \% ; 7.28 \% ; 11.78 \%$, while model III had a relative error of $\mathrm{R}: G=1: 1 ; 1: 3$; and $1: 5$ at $4.86 \% ; 6.79 \% ; 13.31 \%$. The three models each provided the kinetic constants listed in Table 1. The analysis results showed that model II has a better fit because it has the lowest relative error.

This study also observed the esterification reaction at various temperatures to find constants in the Arrhenius equation-A (preexponential factor) and Ea (activation energy). The reaction temperatures were carried out at $180^{\circ} \mathrm{C}, 200^{\circ} \mathrm{C}$, and $220^{\circ} \mathrm{C}$, at atmospheric pressure and a ratio of $R: G=1: 3$. The profile of the acid number of abietic acid against the time at various temperatures can be seen in Figure 3.
Table 1. Evaluation results of kinetic constants in various rosin:glycerol ratios

\begin{tabular}{|c|c|c|c|}
\hline kinetic constants & $R: G=1: 1$ & $R: G=1: 3$ & $R: G=1: 5$ \\
\hline \multicolumn{4}{|l|}{ Model I } \\
\hline$k_{1}, \mathrm{~g} /(\mathrm{mg}$ eq. $\min )$ & $6.00 \times 10^{-4}$ & $1.40 \times 10^{-3}$ & $3.80 \times 10^{-3}$ \\
\hline$k-1, \min ^{-1}$ & $1.17 \times 10^{-5}$ & $7.49 \times 10^{-6}$ & $1.28 \times 10^{-6}$ \\
\hline$k_{2}, \mathrm{~g} /(\mathrm{mg}$ eq. $\min )$ & $1.00 \times 10^{-4}$ & $1.05 \times 10^{-5}$ & $1.07 \times 10^{-4}$ \\
\hline$k-2, \min ^{-1}$ & $1.10 \times 10^{-5}$ & $1.01 \times 10^{-5}$ & $1.12 \times 10^{-5}$ \\
\hline \multicolumn{4}{|l|}{ Model II } \\
\hline$k_{1}, \mathrm{~g} /\left(\mathrm{mg}_{\mathrm{eq}} \cdot \mathrm{min}\right)$ & $6.25 \times 10^{-4}$ & $1.30 \times 10^{-3}$ & $3.90 \times 10^{-3}$ \\
\hline$k_{2}, \mathrm{~g} /\left(\mathrm{mg}_{\mathrm{eq}} \cdot \mathrm{min}\right)$ & $1.31 \times 10^{-4}$ & $1.10 \times 10^{-4}$ & $1.62 \times 10^{-4}$ \\
\hline \multicolumn{4}{|l|}{ Model III } \\
\hline$k_{1}, \mathrm{~g} /\left(\mathrm{mg}_{\mathrm{eq}} \cdot \mathrm{min}\right)$ & $4.50 \times 10^{-4}$ & $8.75 \times 10^{-4}$ & $2.10 \times 10^{-3}$ \\
\hline
\end{tabular}

Figure 3 showed the acid number of abietic acid would be decreased over time. The graphs showed that the higher the reaction temperature causes, the lower the acid number of abietic acid. It caused a higher reaction temperature resulting in the number of carboxylic groups being consumed more. Therefore, at $220^{\circ} \mathrm{C}$, the acid number of abietic was lower than $200^{\circ} \mathrm{C}$, similar to $200^{\circ} \mathrm{C}$ comparing with $180^{\circ} \mathrm{C}$. The increasing reaction temperature caused the carboxylic groups in the abietic acid and the hydroxyl groups in glycerol to collide-the intermolecular interactions increased, and the reaction rate increased.

Moreover, these phenomena were approached by three different models, which are mentioned in section 2.3. Model II provided the best approach because it had the lowest relative error. Respectively, the relative error values at temperatures of $180^{\circ} \mathrm{C}$, $200^{\circ} \mathrm{C}$, and $220^{\circ} \mathrm{C}$ in Model II were $7.28 \%$, $18.85 \%$, and $11.03 \%$. The other models at temperatures of $180^{\circ} \mathrm{C}, 200^{\circ} \mathrm{C}$, and $220^{\circ} \mathrm{C}$ gave larger relative error values (Model $1-7.25 \%$, $19.08 \%$, and $10.97 \%$ and Model III-6, 82\%; $20.08 \% ; 11.15 \%)$. The simulation results using the SSE (Sum Square of Error) method 
showed that the value of the reaction rate constants in each model at various temperatures were presented in Table 2.
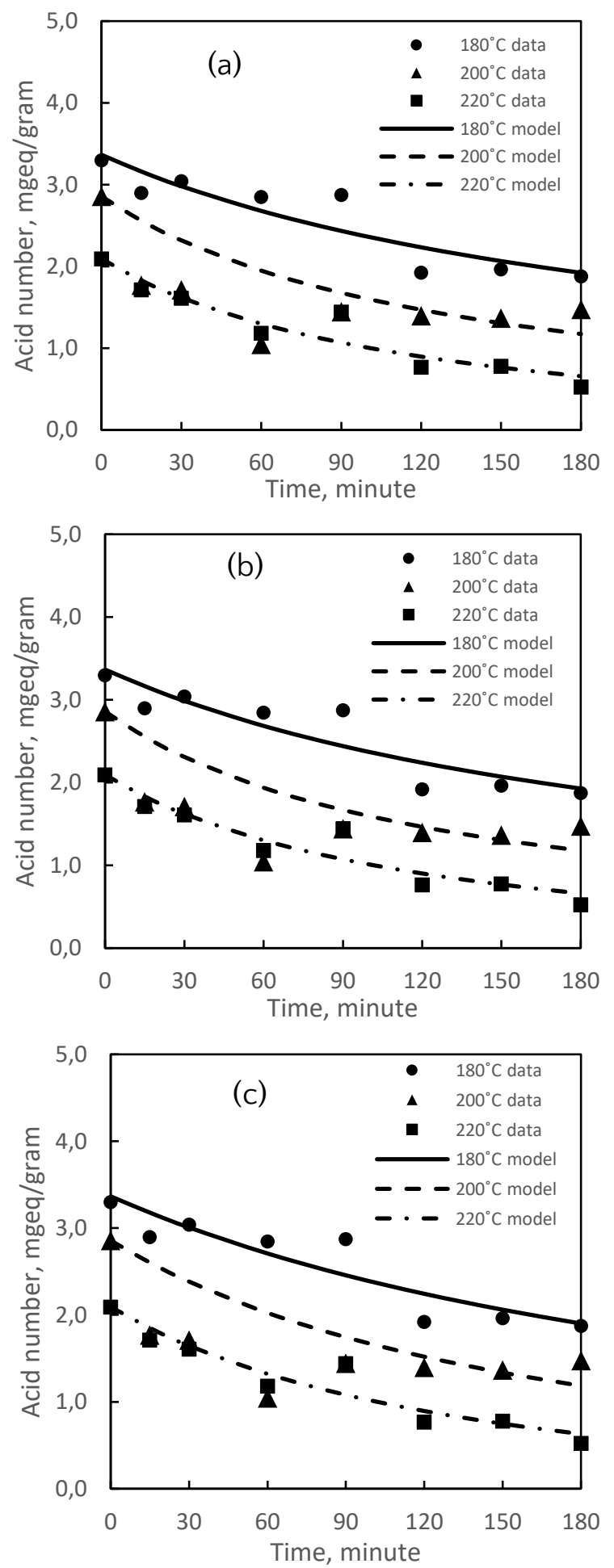

(c)

Figure 3. Data fitting of the acid number on the varying temperature of reaction using Model I (a), model II (b), dan model III (c)
Table 2. Evaluation results of kinetic constants in various temperature reaction

\begin{tabular}{lccc}
\hline kinetic constants & $\mathbf{1 8 0 ^ { \circ } \mathbf { C }}$ & $\mathbf{2 0 0}^{\circ} \mathbf{C}$ & $\mathbf{2 2 0}^{\circ} \mathbf{C}$ \\
\hline Model I & & & \\
$k_{1}, \mathrm{~g} /(\mathrm{mg}$ eq.min) & $1.50 \times 10^{-3}$ & $2.60 \times 10^{-3}$ & $3.20 \times 10^{-3}$ \\
$k_{-1}, \mathrm{~min}-1$ & $7.34 \times 10^{-6}$ & $3.57 \times 10^{-6}$ & $1.33 \times 10^{-6}$ \\
$k_{2}, \mathrm{~g} /\left(\mathrm{mg}_{\text {eq }} \cdot \mathrm{min}\right)$ & $1.09 \times 10^{-4}$ & $1.31 \times 10^{-4}$ & $1.06 \times 10^{-4}$ \\
$k_{-2}, \mathrm{~min}-1$ & $9.76 \times 10^{-6}$ & $1.04 \times 10^{-5}$ & $1.12 \times 10^{-5}$
\end{tabular}

\section{Model II}

$k_{1}, \mathrm{~g} /$ (mg $_{\text {eq. }}$ min) $\quad 1.40 \times 10^{-3} \quad 2.80 \times 10^{-3} \quad 3.20 \times 10^{-3}$ $k_{2}, \mathrm{~g} /\left(\mathrm{mg}_{\text {eq. }} \cdot \mathrm{min}\right) \quad 1.15 \times 10^{-4} \quad 1.06 \times 10^{-5} \quad 1.14 \times 10^{-4}$

Model III

$k_{1}, \mathrm{~g} /\left(\mathrm{mg}_{\text {eq. }} \cdot \min \right) \quad 9.25 \times 10^{-4} \quad 1.50 \times 10^{-3} \quad 2.00 \times 10^{-3}$

Table 2 showed that the forward reaction rate constant increased with temperature. It happened because the addition of temperature caused the reaction rate to be accelerated. Meanwhile, the constant rate value for the backward reaction decreased because the reaction was heading towards the product. The constant rate of reaction value for the backward reaction was very small (per thousandth of a time) compared to the constant forward rate of reaction value, so it can be neglected and assumed that this esterification reaction was irreversible. Therefore the Model II was the most suitable for this reaction. Model II showed that the value of $k_{1}$ was greater than $k_{2}$, which implied the position of the hydroxyl group on glycerol had an effect on this study. The primary hydroxyl group reacted more easily with abietic acid because its steric hindrance was smaller than the secondary hydroxyl group.

Figure 4 illustrated the linearization of $\mathrm{k}_{1}$ and $k_{2}$ on Model II. These equation can be expressed as In $\mathrm{k}_{1}=-4658.8 / \mathrm{T}+3.792$ and $\mathrm{In}$ $\mathrm{k}_{2}=439 \cdot 3 / \mathrm{T}-10,797$. Further analysis showed that the values of $A_{1}$ and $E a_{1}$ were 44.36 $\mathrm{g} /$ (mgeq. in $)$ and $38.72 \mathrm{~kJ} / \mathrm{mol}$, while $A_{2}$ and $\mathrm{Ea}_{2}$ were $2.05 \times 10^{-5} \mathrm{~g} /\left(\mathrm{mg}_{\text {eq. }} \cdot \mathrm{min}\right)$ and $-3.6 \mathrm{~kJ}$ 
$/ \mathrm{mol} \mathrm{Ea}_{2}$ was negative because this value was the overall Ea, which combined the activation energies of various reaction mechanisms. Another study (Zhou et al., 2019) showed that the value of Ea was lower than this study because they employed $\mathrm{ZnO}$ catalyst and Fe3O4/MIL-100(Fe) composite in the esterification reaction rosin and glycerol. The Ea values obtained from their study were $\mathrm{ZnO}$ catalyst and $\mathrm{Fe}_{3} \mathrm{O}_{4} / \mathrm{MIL}-100(\mathrm{Fe}$ ) composite by $25.8-28.8 \mathrm{~kJ} / \mathrm{mol}$ and $33.1-34.4 \mathrm{~kJ} / \mathrm{mol}$, respectively.

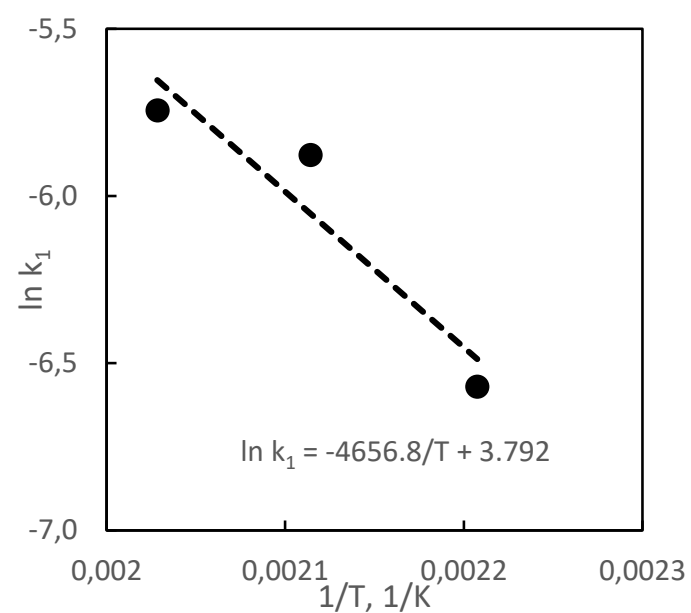

(a)

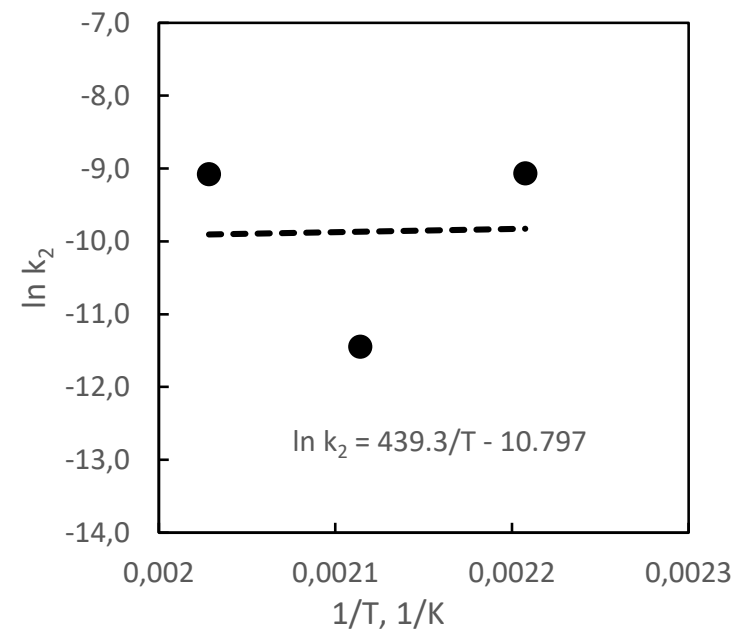

(b)

Figure 4. Arrhenius plot of $k_{1}(a)$ and $k_{2}(b)$ of model II.

FTIR analysis was employed in this research to observe the change of functional group of rosin and glycerolabietate. This analysis was used by the percentage of transmittance data of each species. Based on Figure 4, a prominent characteristic peak at 1697.36 $\mathrm{cm}^{-1}$ was investigated in rosin and glycerolabietate, which is indicated to $-\mathrm{C}=\mathrm{O}$ bond as carboxylate group (Bayu et al., 2019; Lin et al., 2014). The difference of each band was their intensity, in which rosin has 32.69, while glycerolabietate has 16.9. The carboxylate group in the rosin reacted with the hydroxyl group in glycerol to make the ester group, so the amount of carboxylate group in rosin was reduced. At $1273.02 \mathrm{~cm}^{-1}$ line $b$ indicated ester group by streching vibration of -C-O (García et al., 2021).

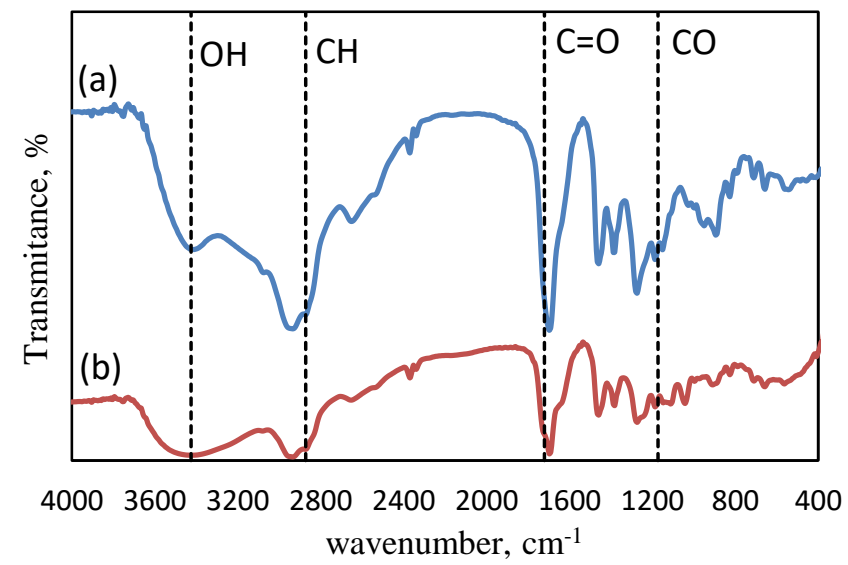

Figure 5. FTIR spectra of rosin (a) and glycerolabietat (b).

In addition, there was a significant peak change at $3200-3570 \mathrm{~cm}^{-1}$. This change can be seen at the peak at $3410.15 \mathrm{~cm}^{-1}$ in rosin and $3425.58 \mathrm{~cm}^{-1}$ in glycerolabietate. It happened because glycerol reacted with abietic acid. The number of $-\mathrm{O}-\mathrm{H}$ groups decreased, resulting in changes, shifts, and broadening of the absorption band of ester (glycerolabietate) (Lin et al., 2014). 


\section{Conclusions}

This research used glycerol to modify rosin as raw monomer become glycerolabietate by the esterification reaction. The change to be an ester group was indicated by FTIR analysis of the differences peaks in rosin and glycerolabietate. The presence of a peak at $1273.02 \mathrm{~cm}^{-1}$ indicates that the ester group was identified. In addition, changes in peaks at $3200-3570 \mathrm{~cm}^{-1}$ and $1697.36 \mathrm{~cm}^{-1}$ exhibited decreases, changes, and vibrations of hydroxyl and carboxylate groups.

The simulation of the reaction kinetics calculation showed that the esterification reaction of abietic acid and glycerol is irreversible. This reaction can be approximated by a second-order kinetics model. The secondary hydroxyl group of glycerol contributed to the formation of glycerolabietate, although this reaction rate constant value was smaller than the primary hydroxyl group. It is denoted that the reaction rate constant between primary hydroxyl and abietic acid was greater than the reaction rate constant between secondary hydroxyl and abietic acid. The values of $A_{1}$ and Ea $a_{1}$ were $44.36 \mathrm{~g} /\left(\mathrm{mg}\right.$ eq. $\mathrm{min}$ ) and $38.72 \mathrm{~kJ} / \mathrm{mol}$, while $A_{2}$ and $\mathrm{Ea}_{2}$ were $2.05 \times 10^{-5} \mathrm{~g} /\left(\mathrm{mg}_{\mathrm{eq}} \mathrm{min}\right)$ and -3.6 $\mathrm{kJ} / \mathrm{mol}$.

\section{Notation}

\section{Nomenclanture}

C = concentration, $\mathrm{mg}_{\mathrm{eq}} / \mathrm{g}$

$k_{1}=$ the forward reaction rate constant of abietic acid (rosin) with the primary

$k^{-1}=$ hydroxyl of glycerol, $\mathrm{g} /\left(\mathrm{mg}_{\mathrm{eq}} /\right.$ minute $)$ the backward reaction rate constant $k_{2}=$ of abietic acid (rosin) with the primary hydroxyl of glycerol, $k-2=g /\left(m_{\text {eq }} /\right.$ minute $)$ the forward reaction rate constant of $m_{\text {sample }}=$ abietic acid (rosin) with the $\mathrm{N}_{\mathrm{NaOH}}=$ secondary hydroxyl of glycerol, $V_{\mathrm{NaOH}}=\mathrm{g} /\left(\mathrm{mg}_{\mathrm{eq}} /\right.$ minute $)$ the backward reaction rate constant of abietic acid (rosin) with the secondary hydroxyl of glycerol, $\mathrm{g} /\left(\mathrm{mg}_{\text {eq }} /\right.$ minute $)$ mass of sample, $\mathrm{g}$ titrant concentration of sodium hydroxide, $\mathrm{mg}$ eq $/ \mathrm{mL}$ titrant volume of sodium hydroxide, $\mathrm{mL}$

\section{Subscripts}

$\mathrm{C}=$ glycerolabietat (primary)

$D \quad=$ glycerolabietat (secondary)

$G_{p} \quad=$ primary hydroxyl of glycerol

$G_{s} \quad=$ secondary hydroxyl of glycerol

$R \quad=$ abietic acid (rosin)

\section{Acknowledgements}

This research was funded by the Department of Chemical Engineering, Engineering Faculty, Universitas Gadjah Mada research grant No. 929/UN1/FTK.2/TK/PT/ 2020. 


\section{References}

Bayu, A., Nandiyanto, D., Oktiani, R. and Ragadhita, R., 2019, Indonesian Journal of Science \& Technology How to Read and Interpret FTIR Spectroscope of Organic Material, Indones. J. Sci. Technol., 4 (1), $97-$ 118.

Bult, R., Hochweber, M., Nielsen, H.K.R., Christensen, G., Hemberg, B., Toussaint, A. and O'Neill, L.., 2008, Recommended Methods for the Analysis of Alkyd Resins, Pure Appl. Chem., 33 (2-3), 411-436.

Caballero, K. V., Guerrero-Amaya, H. and Baldovino-Medrano, V.G., 2019, Revisiting glycerol esterification with acetic acid over Amberlyst-35 via statistically designed experiments: Overcoming transport limitations, Chem. Eng. Sci., Elsevier Ltd, 207, 91-104.

Coates, J., 2000, Interpretation of infrared spectra of soil minerals, Encycl. Anal. Chem., 112 (1), 22-31.

Domene-López, D., Guillén, M.M., MartinGullon, I., García-Quesada, J.C. and Montalbán, M.G., 2018, Study of the behavior of biodegradable starch/ polyvinyl alcohol/rosin blends, Carbohydr. Polym., Elsevier, 202 (September), 299305.

Gandini, A. and Lacerda, T.M., 2015, From monomers to polymers from renewable resources: Recent advances, Prog. Polym. Sci., Elsevier Ltd, 48, 1-39.

García, D.F., Bustamante, F., Villa, A.L. and Alarcón, E.A., 2021, Esterification of rosin with methyl alcohol for Esterificación de colofonia para aplicaciones como combustible CITE THIS ARTICLE AS: ARTICLE INFO:, (100), 10-20.

Hartanto, Danang Tri; Rochmadi, Rochmadi; Budhijanto, B., 2020, Mechanism and kinetic model for glycerolysis of shellac, IOP Conf. Ser. Mater. Sci. Eng., 778, 012053. Heriyanto, H., Budiman, A., Kimia, J.T., Teknik, F., Sultan, U., Tirtayasa, A., Kimia, J.T., et al., 2013, Kinetika Reaksi Alkyd Resin Termodifikasi Minyak Jagung dengan Asam Phtalat Anhidrat, J. Rekayasa Proses, 5 (1), 1-9.

Hsieh, C.C. and Chen, Y.C., 2020, Synthesis of bio-based polyurethane foam modified with rosin using an environmentallyfriendly process, J. Clean. Prod., Elsevier Ltd, 276, 124203.

Kugler, S., Ossowicz, P., Malarczyk-Matusiak, K. and Wierzbicka, E., 2019, Advances in rosin-based chemicals: The latest recipes, applications and future trends, Molecules, 24 (9), available at: https://doi.org/ 10.3390/molecules24091651.

Kumooka, Y., 2008, Analysis of rosin and modified rosin esters in adhesives by matrix-assisted laser desorption/ionization time-of-flight mass spectrometry (MALDITOF-MS), Forensic Sci. Int., 176 (2-3), 111120.

Ladero, M., de Gracia, M., Tamayo, J.J., Ahumada, I.L. de, Trujillo, F. and GarciaOchoa, F., 2011, Kinetic modelling of the esterification of rosin and glycerol: Application to industrial operation, Chem. Eng. J., Elsevier B.V., 169 (1-3), 319-328.

Ladero, M., de Gracia, M., Trujillo, F. and Garcia-Ochoa, F., 2012, Phenomenological kinetic modelling of the esterification of rosin and polyols, Chem. Eng. J., Elsevier B.V., 197, 387-397.

Lin, R., Li, H., Long, H., Su, J. and Huang, W., 2014, Synthesis of Rosin Acid Starch Catalyzed by Lipase, 2014.

Mumtaz, I., Majeed, Z., Ajab, Z., Ahmad, B., Khurshid, K. and Mubashir, M., 2019, 
Optimized tuning of rosin adduct with maleic anhydride for smart applications in controlled and targeted delivery of urea for higher plant's uptake and growth efficiency, Ind. Crops Prod., Elsevier, 133 (March), 395-408.

Satriana, S. and Supardan, M.D., 2008, Kinetic Study of Esterification of Free Fatty Acid in Low Grade Crude Palm Oil using Sulfuric Acid, ASEAN J. Chem. Eng., 8 (1 \& 2), 1.

Su, N., Fang, C., Zhou, H., Tang, T., Zhang, S. and Fei, B., 2021, Hydrophobic treatment of bamboo with rosin, Constr. Build. Mater., 271, available at: https://doi.org/ 10.1016/j.conbuildmat.2020.121507.
Sun, S., Cheng, X., Ma, M., Liu, Y., Wang, G., Yu, H., Liu, S., et al., 2021, High-efficient esterification of rosin and glycerol catalyzed by novel rare earth Lewis acidic ionic liquid: Reaction development and mechanistic study, J. Taiwan Inst. Chem. Eng., Elsevier B.V., 000, available at: https://doi.org/10.1016/j.jtice.2021.07.026.

Xu, Z., Lou, W., Zhao, G., Zhang, M., Hao, J. and Wang, X., 2019, Pentaerythritol rosin ester as an environmentally friendly multifunctional additive in vegetable oil-based lubricant, Tribol. Int., Elsevier Ltd, 135 (February), 213-218. 